\title{
Molecular discrimination of eggs of cervid trematodes using the Teflon (PTFE) technique for eggshell disruption
}

\author{
K. OBERHAUSEROVÁ ${ }^{1 *}$, E. BAZSALOVICSOVÁ ${ }^{2}$ I. KRÁLOVÁ-HROMADOVÁ ${ }^{2}$, P. MAJOR $^{3}$, \\ M. REBLÁNOVÁ ${ }^{2}$
}

\begin{abstract}
${ }^{1 *}$ University of Veterinary Medicine and Pharmacy, Department of Nutrition, Dietetics and Animal Breeding, Košice, Slovakia, E-mail: oberhauserova@uvm.sk, ${ }^{2}$ Parasitological Institute, Slovak Academy of Sciences, Košice, Slovakia; ${ }^{3}$ University of Veterinary Medicine and Pharmacy, Department of Epizootology and Parasitology, Košice, Slovakia
\end{abstract}

\begin{abstract}
Summary
Molecular comparative analysis of eggs of four liver and stomach flukes of cervids and domestic ruminants, Fasciola hepatica, Fascioloides magna, Dicrocoelium dendriticum and Paramphistomum cervi, was performed using a new methodological approach for eggshell disintegration. Eggs of all species were crushed mechanically by the Teflon method (PTFE) without use of chemical reagents and an efficient disruption of eggshell was checked microscopically. The egg suspension was then subjected to DNA isolation and PCR amplification using species-specific primers that annealed to the internal transcribed spacer 2 (ITS2) region of ribosomal DNA. The size of PCR products of individual species corresponded well to the size of amplicons obtained from adult flukes. The results provided evidence that the Teflon method does not destroy the structure of egg DNA, thus making the procedure broadly applicable during coprological examinations. Molecular markers introduced here are particularly important for blanket screening and differentiation of morphologically hardly distinguishable $F$. hepatica, $F$. magna and $P$. cervi eggs.
\end{abstract}

Keywords: liver and stomach flukes; ruminants; eggs; ribosomal internal transcribed spacer 2; PTFE homogenizer

\section{Introduction}

The intestinal and liver flukes (Platyhelminthes; Trematoda) parasitizing broad range of cervids and domestic ruminants, belong to the genera Fasciola, Fascioloides, Dicrocoelium, and Paramphistomum (Dorchies, 2006; Sanabria et al., 2009). Common liver fluke Fasciola hepatica and giant liver fluke (or large American fluke) Fascioloides magna (Fasciolidae) occur in bile ducts and parenchymatous cysts within the liver of infected ruminants, respectively (Špakulová et al., 2003). The lancet (small liver) fluke Dicrocoelium dendriticum (Dicrocoeliidae) affects bile ducts, gall bladder and stomach fluke Paramphistomum cervi (Paramphistomidae) is the parasite of fore stomach (rumen and reticulum) of definitive hosts (Otranto \& Traversa, 2003; Rieu et al., 2007). All the flukes are of veterinary importance, $F$. hepatica has also caused epidemics of human fasciolosis in several world regions (Mas-Coma, 2005; Špakulová, 2009).

Due to a negative impact of the liver and stomach flukes on health of their animal hosts (decreased milk and meat production, reduction of body mass, trophy, reproduction capacity, suppression of immune response, etc.) (Wolff et al., 1984; Ramajo et al., 2001; Dorchies, 2007; Rieu et al., 2007), reliable in vivo diagnostic methods are highly needed for this helminth group. However, differential diagnosis of $F$. hepatica, F. magna, D. dendriticum and $P$. cervi infections is difficult mainly due to their very similar clinical signs.

Currently, a variety of diagnostic techniques of different sensitivity and specificity levels are available for the species delineation. The most frequent in vivo diagnostic approaches are immunological methods such as ELISA, immunofluorescence test, copro-antigen methods, etc. Although immunological methods are regarded as having high reliability, their efficiency is low in prolonged infections and low parasite burden (Dorchies, 2007).

Coprological examinations have also been frequently applied for species determination (Conceição et al., 2002; Dorchies, 2007). In general, these methods are simple to perform, no time-consuming and can be achieved without expensive chemical requirements. Nevertheless, similarities in size and structure of $F$. hepatica, F. magna and even $P$. cervi eggs present serious obstacle for unequivocal species differentiation by coprology.

Molecular approaches employing PCR-based techniques using species-specific primers are recommended in cases when propagative stages of flukes are morphologically 
hardly distinguishable (Králová-Hromadová et al., 2008). Prior to molecular diagnostics of trematode eggs, DNA has to be released from eggs by disintegration of eggshell using glass or ceramic beads, sonication, boiling/freezing, etc. For this purpose, a modified Teflon method, originally designed for homogenisation of soft tissues like brain, liver or whole worm bodies, has been also applied (Turčeková et al., 1986; Harder et al., 1995; Skálová et al., 2007; Goldberg et al., 2008). In trematodes, eggs of Schistosoma mansoni were disintegrated by sonication (Boros et al., 1970) and modified Teflon method (Ramalho-Pinto et al., 1976) to obtain the soluble egg antigen. In another fluke Opistorchis viverrini, eggshell was crushed using chemical pre-treatment, autoclaving and homogenisation with ceramic tissue grinder on liquid nitrogen (Stensvold et al., 2006; Duenngai et al., 2008). The same principle of homogenization was also applied for disintegration of eggs of Haplorchis taichui, Stellantchasmus falcatus, Opistorchis viverrini, Ganeo tigrinus, Paramphistomum epiclitum, and Fischoederius elongatus (Wongsawad et al., 2006).

The aim of the current work was to test the Teflon method as a methodological approach originally applied for a disintegration of eggshells of liver and stomach flukes $F$. hepatica, F. magna, D. dendriticum and P. cervi. The efficiency of the method was checked microscopically and followed by the amplification of egg DNA using ribosomal internal transcribed spacer 2 (ITS2) species-specific primers. Intraspecific variation within the ITS2 region has recently been evaluated in worldwide geographic populations of all four flukes (Králová-Hromadová et al., 2008; Bazsalovicsová et al., 2010). The studies revealed low (F. hepatica, D. dendriticum) or no (F. magna, P. cervi) intraspecific variation and consistent interspecific differences amongst the four liver and stomach flukes. Selected regions within ITS2 spacer which exhibited no intraspecific variation and showed interspecific sequence heterogeneity, were applied for design of species-specific primers as promising markers in taxonomic and population studies of the flukes (Králová-Hromadová et al., 2008; Bazsalovicsová et al., 2010). The primers were utilized for amplification of species-specific ITS2 regions on DNA isolated from eggs of studied species.

\section{Materials and methods}

\section{Isolation of eggs}

Eggs of $F$. hepatica, F. magna, D. dendriticum and $P$. cervi were subjected to molecular analysis. Data on their origin are summarised in Table 1. Eggs of $F$. hepatica were released from the uterus of one adult fluke individual on a watch-glass filled with water, using a stereomicroscope. Eggs were several times washed (decanted) and stored in tap water at $4^{\circ} \mathrm{C}$ in plastic tubes. Fascioloides magna eggs were isolated directly from the parenchymatous cysts during the deer liver dissection. Liver was cut into $10 \mathrm{~mm}$ wide slices, which were rinsed in water in a 10-litre plastic bin. Eggs were let to sediment for $30 \mathrm{~min}$, supernatant was removed and the process was repeated until the supernatant was clean. Finally, eggs were stored in plastic tubes filled with tap water and kept at $4^{\circ} \mathrm{C}$. For isolation of $D$. dentriticum and $P$. cervi eggs from the faeces, standard sedimentation technique was used. Several batches per 6 grams of positive faecal samples were homogenised with water in the mortar. Each mixture was sieved through a $2 \mathrm{~mm}$ mesh sieve into the $50 \mathrm{ml}$ beaker, filled with water and let to sediment for 20 minutes. Supernatant was discarded and water was added into sediment; the process was repeated 5 times. The final sediment containing eggs was stored as described above.

Finally, water suspensions of eggs of $F$. hepatica, $F$. magna, D. dendriticum and $P$. cervi were purified using the faecal sieving-staining method (FSSM) modified by Kleiman et al. (2005). For a long-time storage of the viable eggs at $4^{\circ} \mathrm{C}$, the water was replaced by a tap water solution of $0.05 \%$ chloramine $\mathrm{B}$ to prevent fungal contamination.

A small portion of each egg suspension was dropped onto a slide, covered by coverslip and 10 eggs of each species were measured using light microscope Olympus BX41 equipped by digital camera Olympus E.

\section{Disintegration of eggshells by Teflon method}

Prior to isolation of DNA from eggs, eggshell was disintegrated mechanically by modified homogenisation technique, using Wheaton Potter-Elvehjem tissue grinder with PTFE piston (Fischer Scientific, Pardubice, Czech Republic) with round bottom (,piston-tube“" system), originally

Table 1. Origin of eggs of Fasciola hepatica, Fascioloides magna, Dicrocoelium dendriticum and Paramphistomum cervi used in the study

\begin{tabular}{llll}
\hline Fluke species & Host & $\begin{array}{l}\text { Eggs isolated } \\
\text { from }\end{array}$ & Locality \\
\hline Fasciola hepatica & $\begin{array}{l}\text { cattle (Bos taurus f. domestica) } \\
\text { slaughtered }\end{array}$ & $\begin{array}{l}\text { uterus of adult } \\
\text { F. hepatica }\end{array}$ & Zakamenné, Slovakia \\
Fascioloides magna & $\begin{array}{l}\text { red deer (Cervus elaphus) } \\
\text { hunted }\end{array}$ & liver cysts & Bodíky, Slovakia \\
Dicrocoelium dendriticum & mouflon (Ovis musimon) & faecal samples & $\begin{array}{l}\text { Game parks Janovice and Vlkov, } \\
\text { Czech Republic }\end{array}$ \\
Paramphistomum cervi & red deer (Cervus elaphus) & faecal samples & Bodíky, Slovakia \\
\hline
\end{tabular}




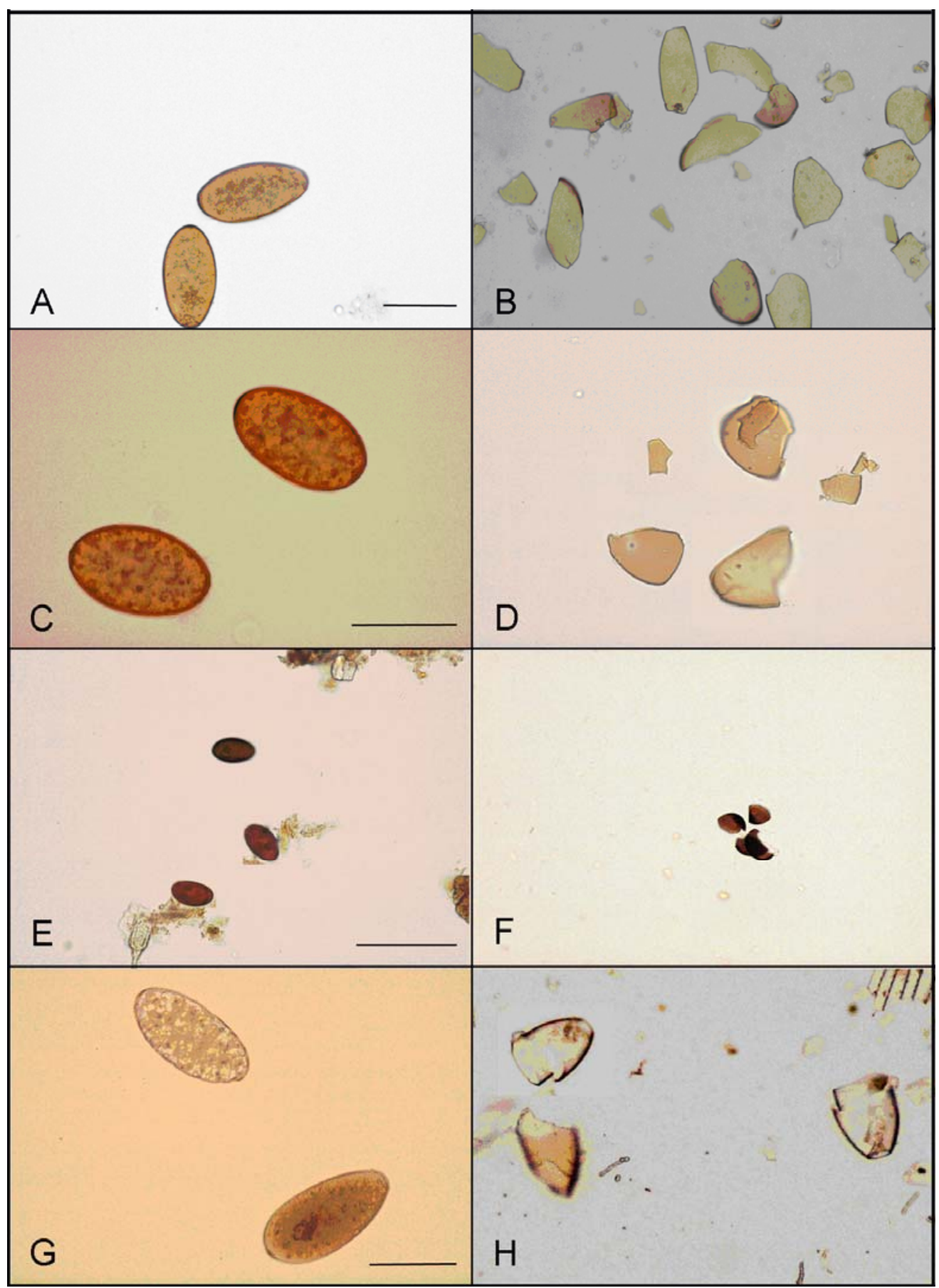

Fig. 1. Eggs of Fasciola hepatica (A, B), Fascioloides magna (C, D), Dicrocoelium dendriticum (E, F) and Paramphistomum cervi (G, H) before (A, C, E, G) and after (B, D, F, H) treatment with PTFE homogeniser. Scale bar $=100 \mu \mathrm{m}$

used for soft tissue homogenisation (Goldberg, 2008). The piston made from PTFE (polytetrafluoroethylene, Teflon) was fixed to high rotation speed drive (electric drill, 2500 $\mathrm{rpm}$ ), with $\sim 0.1 \mathrm{~mm}$ aperture between piston and tube. Egg suspension $(2 \mathrm{ml})$ was poured into the borosilicate glass tube and piston was rotated for 2 minutes. Collaterally, the system was cooled down by sinking to water mixed with ice cubes in order to avoid a risk of DNA degradation. Efficiency of eggs disintegration was controlled using a stereomicroscope.

\section{DNA isolation, PCR amplification}

For DNA extraction of $F$. hepatica and $F$. magna eggs, concentrated disintegrated eggs suspensions was incubated in extraction buffer $(10 \mathrm{mM}$ TRIS-HCl, $\mathrm{pH} 7.5 ; 10 \mathrm{mM}$ EDTA; $50 \mathrm{mM} \mathrm{NaCl} ; 2 \%$ sodium dodecyl sulphate) supplemented with $20 \mathrm{mM}$ dithiothreitol and $900 \mu \mathrm{g}$ proteinase $\mathrm{K}$ at $56^{\circ} \mathrm{C}$ with gentle shaking for $12-18$ hours. After lysis, phenol:chlorophorm:isoamylalcohol (25:24:1) extraction and ethanol precipitation (100\% ethanol; $3 \mathrm{M}$ sodium acetate; $\mathrm{pH} 4.8$ ) were performed. Genomic DNA 
was diluted in $20 \mu \mathrm{l}$ of deionized water and stored in $20^{\circ} \mathrm{C}$. DNA extraction of $D$. dendriticum and $P$. cervi eggs obtained from faecal samples was carried out with QIAamp DNA Stool Mini Kit (Qiagen, Hilden, Germany), following the manufacturers' recommendations.

PCR conditions, sequences and annealing positions of species-specific primers, employed in the current work, were described in detail in studies of Králová-Hromadová et al. (2008) and Bazsalovicsová et al. (2010).

\section{Results and Discussion}

Eggs of $F$. hepatica, isolated directly from uterus of an adult worm, measured in average $145 \mu \mathrm{m}$ in length and 70 $\mu \mathrm{m}$ in width and were shaped as symmetric regular ellipse with thin shell and operculum at one pole. Granular greyyellow contents filled whole eggs (Fig. 1A). Fascioloides magna eggs, isolated from the liver cysts, were also of symmetric elliptical shape, with operculum at one pole. The average size of eggs was $150 \mu \mathrm{m}$ long and $80 \mu \mathrm{m}$ wide. Eggs were filled with rough granular content of intensive yellow colour (Fig. 1C). Eggs of D. dentriticum, isolated from mouflon faeces had asymmetric shape typical for the fluke species, with operculum at one pole. The eggs were significantly smaller $(30-40 \mu \mathrm{m}$ in length and $25-$ $30 \mu \mathrm{m}$ in width), than those of other three fluke species (Fig. 1E). A homogeneous dark brown content of the eggs was usually seen; however, some eggs contained mature larval stage, miracidium. Proportions of $P$. cervi eggs (145 $-155 \mu \mathrm{m}$ in length and $75-80 \mu \mathrm{m}$ in width, Fig. 1G) markedly resemble those of $F$. hepatica and $F$. magna. Other similarities with eggs of $F$. hepatica and $F$. magna were associated with elliptical shape, existence of operculum at one pole, grey-yellowish to brownish colour and granular internal content. Generally, eggs of flukes like $F$. hepatica, F. magna and even $P$. cervi, found during coprological analyses, are considered to be hardly distinguishable (Rieu et al., 2007; Valero et al., 2009).

Before we have established the Teflon technique for the mechanical disruption of the eggshells into pieces, we had employed other techniques such as repeated heating/cooling (boiling water/liquid nitrogen) of egg suspension, or homogenization with glass beads. However, subsequent DNA isolation and PCR amplification did not provide expected results.

After a treatment with the Teflon method, microscopy inspection of egg suspensions revealed that eggshells were successfully crushed all four fluke species (Fig. 1B, D, F, $\mathrm{H})$. The eggshell fragments clearly differed from surrounding artefacts and possessed either the same or slightly brighter colour as intact eggs.

A non-destructive DNA deliverance and the efficiency of Teflon disintegration of eggshells were tested by DNA isolation and following PCR amplification with speciesspecific ITS2 primers that annealed to targeted DNA of the particular species (Fig. 2). The PCR products were of corresponding size as amplicons obtained on genomic DNA isolated from adult flukes (Bazsalovicsová et al., 2010).
In summary, the presented work provides data on application of Teflon method to successfully achieve disintegration of eggshell of liver and stomach flukes of ruminants. The technique is easy to perform, no time-consuming and does not require special chemical treatment. It also provides opportunity to isolate intact DNA from eggs from coprological samples that is especially important for the accurate determination of fluke species of cervids using molecular analysis of faecal samples. Respective molecular approach is particularly useful for differentiation of eggs of parasites that lack suitable morphological discriminatory markers, e.g. for F. hepatica, F. magna and P. cervi eggs.

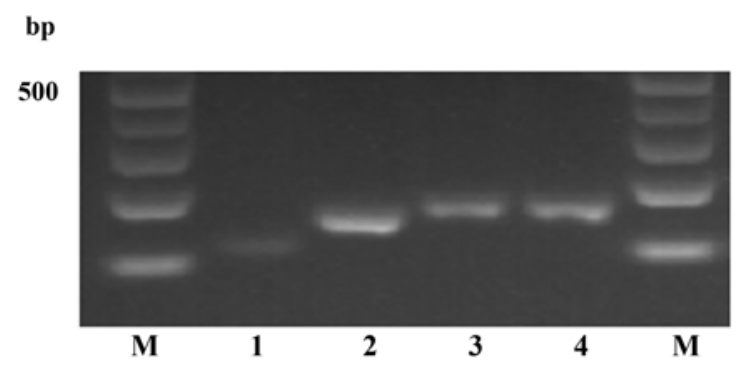

Fig. 2. PCR amplification performed on DNA isolated from eggs of Fasciola hepatica (lane 1), Fascioloides magna (lane 2),

Dicrocoelium dendriticum (lane 3), and Paramphistomum cervi (lane

4) using respective species-specific ITS2 primers. $\mathrm{M}$ - molecular marker 100 bp ladder (Fermentas, Vilnius, Lithuania)

\section{Acknowledgement}

The authors would like to acknowledge Assoc. Prof. D. Rajský (Technical University in Zvolen, Faculty of Forestry, Zvolen, Slovakia), Prof. J. Lamka and Assoc. Prof. L. Skálová (Charles University, Faculty of Pharmacy in Hradec Králové, Hradec Králové, Czech Republic) for providing us with material. We sincerely thank Dr. Marta Špakulová (Parasitological Institute SAS, Košice, Slovakia) for critical readings of the manuscript and valuable comments. The work was supported by the Slovak Research and Development Agency under contracts APVV51-062205 and LPP-0126-07. The study was realized in frame of the project "Centre of Excellence for Parasitology" (Code ITMS: 26220120022), based on the support of Operational Programme "Research \& Development" funded from the European Regional Development Fund (rate 0.3 ).

\section{References}

BAZSAlOVICSOVÁ, E., KRÁlOVÁ-HROMAdOVÁ, I., ŠPakulová, M., Reblánová, M., Oberhauserová, K. (2010): Determination of ribosomal internal transcribed spacer 2 (ITS2) interspecific markers in Fasciola hepatica, Fascioloides magna, Dicrocoelium dendriticum and $\mathrm{Pa}$ ramphistomum cervi (Trematoda), parasites of wild and domestic ruminants. Helminthologia, 47(2): $76-82$ Boros, L., Kenneth, S., WArren, M. D. (1970): Hypersensitivity-type granuloma formation and dermal reaction 
induced and elicited by a soluble factor isolated from Schistosoma mansoni. J. Exp. Med., 132(3): 488 - 507

Conceição, M. A. P., DurÃo, R. M., CostA, I. H., CorreiA DA CostA, J. M. (2002): Evaluation of a simple sedimentation method (modified McMaster) for diagnosis of bovine fascioliosis. Vet. Parasitol., 105(4): $337-343$. DOI: 10.1016/S0304-4017(02)00016-X

DORCHIES, P. (2006): Flukes: Old parasites but new emergence. In Manuscript of 24th World Buiatrics Congress, Nice, France, 15-19 October, 2006. Ecole Nationale Vétérinaire, Toulouse, France, 2006.

DORCHIES, P. (2007): Comparison of methods for the veterinary diagnosis of liver flukes (Fasciola hepatica) in cattle. Bulletin USAMV-CN, 64(1-2): 14 - 19. ISSN 1454-2382

Duenngai, K., Sithithaworn, P., Rudrappa, U. K., IDDYA, K., LAHA, T., STENSVOLD, C. R., StRAndGAARD, H., JOHANSEN, M. V. (2008): Improvement of PCR for detection of Opisthorchis viverrini DNA in human stool samples. J. Clin. Microbiol., 46(1): 366 - 368. DOI: 10.1128/JCM.01323-07

GoldBERG, S. (2008): Mechanical/physical methods of cell disruption and tissue homogenization. Methods Mol. Biol., 424: 3 - 22. DOI: 10.1007/978-1-60327-064-9_1

HARDER, A., DANNESCHEWSKI, A., Wunderlich, F. (1995): Egg deposition of the intestinal nematode Heterakis spumosa: stimulation by soluble colon factors of mice. J. Parasitol., 81(5): 733 - 735

Kleiman, F., Pietrokovsky, S., Gil, S., WisniveskyColli, C. (2005): Comparison of two coprological methods for the veterinary diagnosis of fasciolosis. Arq. Bras. Med. Vet. Zootec., 57(2): 181 - 185. DOI: 10.1590/S010209352005000200007

KrÁlovÁ-HromadovÁ, I., ŠPAKUlovÁ, M., HorÁČKOVÁ, E., TurČEKOvÁ, L., NovobilskÝ, A., BECK, R., KoudelA, B., Marinculić, A., Rajský, D., Pybus, M. (2008): Sequence analysis of ribosomal and mitochondrial genes of the giant liver fluke Fascioloides magna (Trematoda: Fasciolidae): intraspecific variation and differentiation from Fasciola hepatica. J. Parasitol., 94(1): 58 - 67. DOI: 10.1645/GE-1324.1

Mas-Coma, S., Bargues, M. D., Valero, M. A. (2005): Fascioliasis and other plant-borne trematode zoonoses. Int. J. Parasitol., 35(11-12): 1255 - 1278. DOI: 10.1016/ j.ijpara.2005.07.010

Otranto, D., Traversa, D. (2003): Dicrocoeliosis of ruminants: a little known fluke disease. Trends in Parasitol., 19(1): 12 - 15. DOI: 10.1016/S1471-4922(02)00009-0 Ramajo, V., Oleaga, A., Casanueva, P., Hillyer, G. V., Muro, A. (2001): Vaccination of sheep against Fasciola hepatica with homologous fatty acid binding proteins. Vet. Parasitol., 97(1): 35 - 46. DOI: 10.1016/S0304-4017(01) 00388-0

Ramalho-Pinto, F. J., Goldring, O. L., SMithers, S. R.,
Playfair, J. H. L. (1976): T-cell helper response to antigens of Schistosoma mansoni in CBA mice. Clin. Exp. Immunol., 26(2): 327 - 333

Rieu, E., Recca, A., Benet, J. J., SaAna, M., DorchiES, P., Guillot, J. (2007): Reliability of coprological diagnosis of Paramphistomum sp. infection in cows. Vet. Parasitol., 146(3 - 4): 249 - 253. DOI: 10.1016/ j.vetpar.2007.02.033

SAnABria, R. E. F., Martorelli, S. R., Romero, J. R. (2009): First report of Paramphistomum leydeni Näsmark, 1937 (Trematoda: Paramphistomidae) in Argentina, and reexamination of Cotylophoron cotylophorum sensu Racioppi et al. (1994). Helminthologia, 46(4): 225 - 229. DOI: $10.2478 / \mathrm{s} 11687-009-0042-7$

SkÁlová, L., Krízová, V., CVILINK, V., SzOTÁKOVÁ, B., STORKÁNOVÁ, L., VELÍK, J., LAMKA, J. (2007): Mouflon (Ovis musimon) dicrocoeliosis: effects of parasitosis on the activities of biotransformation enzymes and albendazole metabolism in liver. Vet Parasitol., 146(3 - 4): 254 - 262. DOI: 10.1016/j.vetpar.2007.02.026

Stensvold, C. R., Saijuntha, W., Sithithaworn, P., WongratanacheEWIN, S., STRANDGAard, H., ØRNBJERG, N., JOHANSEN, M. V. (2006): Evaluation of PCR based coprodiagnosis of human opisthorchiasis. Acta Trop., 97(1): 26 - 30. DOI: 10.1016/j.actatropica.2005.08.008

ŠPAKUlOVÁ, M. (2009): Fasciolosis. In: DORKO, PISTL, J., MiterpÁKovÁ, M. (Eds) Bacterial, viral, parasitic and mycotic diseases. Volume 2. Košice, SR: Faculty of Medicine, Pavol Jozef Šafárik University and University of Veterinary Medicine and Pharmacy, Košice, pp. 280 - 282 (In Slovak)

ŠPAKUlOVÁ, M., RAJSKÝ, D., SOKOL, J., VODŇANSKÝ, M. (2003): Giant liver fluke (Fascioloides magna), an important parasite of ruminants. Bratislava, SR: PaRPRESS, 77 pp.

TurČEKovÁ, L., ZEMEK, J., DuBinskÝ, P., RYBOŠ, M. (1986): Phosphorylase $a$ and $b$ activity in the muscles and reproductive organs of Ascaris suum females. Helminthologia, 23: 79 - 84

Valero, M. A., Perez-Crespo, I., Periago, M. V., KhOUBBANE, M., MAS-COMA, S. (2009): Fluke egg characteristics for the diagnosis of human and animal fascioliasis by Fasciola hepatica and F. gigantica. Acta Trop., 111(2): 150 - 159. DOI: 10.1016/j.actatropica.2009.04.005 Wolff, K., Hauser, B., Wild, P. (1984): Dicrocoeliose des Schafes: Untersuchungen zur Pathogenese und zur Regeneration des Leber nach Therapie. Berl. Münch. Tierärztl. Wschr., 97: $378-387$

Wongsawad, C., Wongsawad, P., ChaI, J. Y., Paratasilpin, T., AnUntalabhochai, S. (2006): DNA quantities and qualities from various stages of some trematodes using optical and HAT-RAPD methods. Southeast Asian J. Trop. Med. Public. Health 37(suppl. 3): 62 - 68. ISSN 0125-1562 